\title{
SCIDOC
}

\author{
International Journal of Dentistry and Oral Science (IJDOS) \\ ISSN: 2377-8075
}

\section{Factors Influencing The Risk Of COVID-19 In Rural and Urban Populations - A Questionnaire Survey}

Research Article

Leslie Rani ${ }^{* *}$, Aditi Chopra ${ }^{2}$, Brundha ${ }^{3}$, Jayalakshmi Somasundaram ${ }^{4}$

${ }^{1}$ Lecturer, Department of General Pathology, Saveetha Dental College and Hospitals, Saveetha Institute of Medical and Technical Sciences, Saveetha University, Chennai, Tamil Nadu, India.

${ }^{2}$ Saveetha Dental College and Hospitals, Saveetha Institute of Medical and Technical Sciences, Saveetha University, Chennai, Tamil Nadu, India. ${ }^{3}$ Associate Professor, Department of General Pathology, Saveetha Dental College and Hospitals, Saveetha Institute of Medical and Technical Sciences, Saveetha University, Chennai, Tamil Nadu, India.

${ }^{4}$ Chief scientist, White Lab - Material research centre, Saveetha Dental College and Hospitals, Saveetha Institute of Medical and Technical Sciences, Saveetha University, Chennai, Tamil Nadu, India.

\section{Abstract}

\begin{abstract}
Aim: The aim of the study is to analyse the factors influencing the risk of COVID 19 among urban and rural populations. The pandemic of coronavirus has become the talk of the world nowadays. The community which is divided in to urban and rural populations has been largely affected. The rural, having poor hygiene, less immunity, and no preventive and protective measures are considered to be at a higher risk of COVID-19. In comparison, population density and migrants are very important risk factors for the urban population. A number of factors come in to play when determining which community is at a higher risk of getting infected.

Materials and Methods: A survey questionnaire of 15 questions was prepared using an online survey portal and was circulated among two groups namely, urban and rural. The data was collected in the year 2020 in the months of March to May. Results and Discussion: Descriptive statistics were expressed by means of frequency and percentage. Chi-square test was used to find the association between the variables and $\mathrm{p}$ value was calculated. The present studies show the general public has an opinion that urban people will be affected more as they are very densely populated and are not following the self preventive measures during the pandemic of COVID-19. This is despite the urban population having many facilities such as masks, and sanitisers which they are able to afford for their protection against the life threatening virus.

Conclusion: The present study shows that the urban population is suffering more because it has a higher risk of coronavirus due to dense population, lower immunity and disobedience towards social distancing norms. Though the amenities are inadequate in rural are as, the spread of COVID 19 is under control in rural populations.
\end{abstract}

Keywords: COVID-19; Coronavirus; Pandemic; Urban; Rural.

\section{Introduction}

The pandemic of coronavirus is one that has become the talk of the world nowadays. It's rapid and fast spread has shocked everyone. The well-known coronavirus disease that emerged at the end of 2019 began threatening the health and lives of lakhs of people after a few weeks [1]. Health officials and medical professionals are struggling with the containment of the disease and testing and treating affected people [2]. It has spared no community, neither rural or urban populations [3]. Coronavirus is a collection of viruses that causes diseases in mammals and birds. In humans, these viruses cause respiratory tract infection that can range from mild to severe [4]. Mild illnesses can include some cases of common cold while lethal cases include SARS \& COVID-19 [5]. Coronavi-

\section{*Corresponding Author:}

Leslie Rani,

Lecturer, Department of Pathology, Saveetha Dental College and Hospitals, Saveetha Institute of Medical and Technical Sciences (SIMATS), Saveetha University, 162, PH Road, Chennai 600077 Tamil Nadu, India.

Tel: 9360293308

Email Id: leslierani.sdc@saveetha.com

Received: February 25, 2021

Accepted: March 04, 2021

Published: March 08, 2021

Citation: Leslie Rani, Aditi Chopra, Brundha, Jayalakshmi Somasundaram. Factors influencing the risk of COVID-19 in rural and urban populations - A questionnaire survey. Int J Dentistry Oral Sci. 2021;08(03):1970-1976. doi: http://dx.doi.org/10.19070/2377-8075-21000389

Copyright: Leslie Rani ${ }^{\circ}$ 2021. This is an open-access article distributed under the terms of the Creative Commons Attribution License, which permits unrestricted use, distribution and reproduction in any medium, provided the original author and source are credited. 
rus 19 is an infectious disease caused by severe acute respiratory syndrome coronavirus-2 (SARS-COV2) [6]. It was first identified in Wuhan, China and has since spread globally, resulting in a pandemic. Common symptoms include fever, cough, fatigue, shortness of breath and loss of smell and taste [7]. It can also lead to multiple organ failures, septic shocks, and blood clots [8]. The virus mainly spreads between people during close/direct contact via small droplets produced by coughing, sneezing, and talking [9]. Recommended measures to prevent infection include frequent hand washing, maintaining physical distance from others, self quarantine, face covering and sanitising regularly $[10,11]$. These preventive measures should be taken seriously as there are no vaccines nor specific treatments for infection [12].

As stated earlier, the virus spread is equal in all communities and is infecting people from around the country alike [13]. However, in comparison between rural and urban populations, many factors come in to play to determine which population has a higher risk of contracting the virus [14]. One major factor that should be considered is population density of both areas. Undoubtedly, urban cities are more densely populated [15]. However, the initiation of lockdown comes into play here. Since more people means higher transmission and vast spread of the disease, it is certain that urban areas are at a higher risk. But, since the lockdown has been forcefully implemented by the government, it nullifies this factor. Another very important factor is awareness [16]. Rural areas are generally less aware of such situations and so, the pandemic and lockdown news was understood very late by them. Because of this, strict following of the lockdown and self quarantine regime started at a delayed time and so transmission and spread of the virus was not in control at that time [17]. In comparison, urban populations are known to not follow lockdown and self quarantine very rigorously.

The aim of this survey is to observe and analyse the hardships of the rural and urban populations during the pandemic of COVID-19. This is done to conclude which of these communities are at a higher risk of getting infected with coronavirus.

\section{Materials and Methods}

A cross sectional questionnaire survey was conducted during April 2020 - May 2020.

In order to assess the awareness level, environmental factors (such as media and timely updates) and information appraisal skills, 15 self structured questions were prepared. The questionnaire survey was distributed among two groups of the public, namely, urban and rural. Both groups consisted of an equal number of people, i.e. 50 each. This survey was used as a medium to interpret which community is at a higher risk of contracting the virus. The survey questions were prepared as such, to focus on gathering information regarding proximal active cases and deaths due to COVID-19, availability of healthcare facilities, adequate income and practicing of self preventive measures. The online questionnaire was developed and circulated with the help of social media platforms. Statistical analysis was done using the SPSS software version 20.0. Descriptive statistics were expressed by means of frequency and percentage. Chi-square test was used to find the association between the variables and $\mathrm{p}$ value was calculated.

\section{Results}

The COVID-19 pandemic has had a major impact on human life, be it the rural or urban [18]. To conduct the survey, a total of hundred people were chosen equally from both communities. The people were chosen at random, from the general population. The people belonged to the state of Tamil Nadu, India.

Figure 1 shows that $50 \%$ of the people who answered the survey questions are from urban backgrounds, where as 50\% are from rural backgrounds. Figure 2 shows that $75 \%$ of the respondents reported that they have been getting recent updates on the pandemic, out of which $40 \%$ are urban and 35\% are rural, $25 \%$ reported the opposite (where $10 \%$ belong to urban community and $15 \%$ belong to rural community). Figure 3 shows that $54 \%$ of the respondents, out of which, $31 \%$ are urban and $23 \%$ are rural, feel that they have adequate income in comparison to $25 \%$ respondents who responded with 'no'. Figure 4 shows that $65 \%$ of the respondents reported that they have active cases of coronavirus in their locality, where $40 \%$ are urban and $25 \%$ are rural, whereas $35 \%$ reported the opposite, in which $10 \%$ are urban and $25 \%$ are rural. Figure 5 shows that $54 \%$ of the respondents reported that they are aware of deaths due to coronavirus in their locality, where $30 \%$ are urban and $24 \%$ are rural, where as $25 \%$ reported the opposite and the remaining $21 \%$ are not sure. Figure 6 Shows that $68 \%$ of the respondents reported that they have sufficient medical services near them, which consists of $44 \%$ urban population and $24 \%$ rural population, where as $32 \%$ reported the opposite. Figure 7 shows that $75 \%$ of the respondents reported that they have been practicing self preventive methods, in which $35 \%$ are urban and $45 \%$ are rural, where as $25 \%$ reported the op-

Figure 1. Bar graph representing association between community background and awareness about pandemic of COV-

ID-19. $\mathrm{X}$ axis represents the community background and the $\mathrm{Y}$ axis represents the number of responses. Urban population has higher awareness regarding COVID-19 pandemic than the rural population. However, there is no statistical difference between the community background and awareness on COVID 19 pandemic. Chi square analysis was done, Pearson Chi SquareValue $=0.709$, the $P$ value was $0.400(p>0.05)$, not found to be statistically significant.

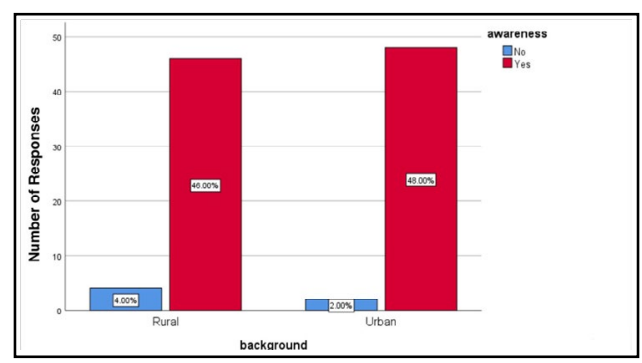


Figure 2. Bar graph representing association between community background and responses about receiving adequate information and updates on COVID-19. $\mathrm{X}$ axis represents the community background and $\mathrm{Y}$ axis represents the number of responses. Urban population received more updates and information regarding coronavirus than the rural population. However, there is no statistical difference between community background and responses about receiving adequate information and updates on COVID-19. Chi square analysis was done, Pearson Chi SquareValue $=1.333$, the $P$ value was 0.248 $(\mathrm{p}>0.05)$, and was not found to be statistically significant.

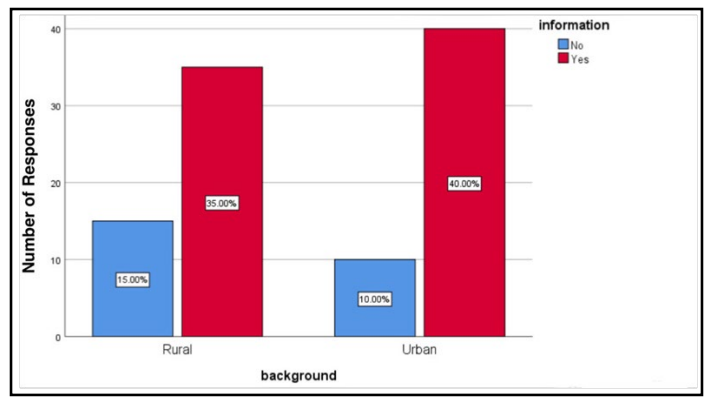

Figure 3. Bar graph representing the association between community background and responses about having adequate income. $\mathrm{X}$ axis represents the community background and $\mathrm{Y}$ axis represents number of responses. Adequate income was found more among the urban population than the rural populations. Chi square analysis was done, Pearson Chi SquareValue $=9.136$, the $P$ value was $0.010,(p<0.05)$ which was found to be statistically significant. There is a significant increase seen in the urban population who have adequate income during COVID 19 pandemic.

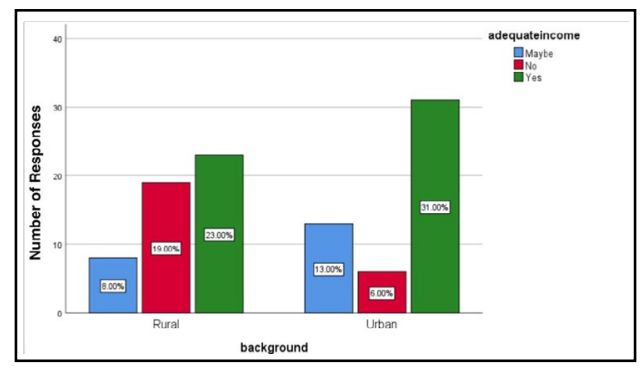

Figure 4. Bar graph representing association between community background and percentage of active cases of COVID-19. $\mathrm{X}$ axis represents the community background and $\mathrm{Y}$ axis represents the number of responses. Most of the urban population $(40 \%)$ has reported to have active cases of coronavirus in their locality, compared to $25 \%$ of rural population. Chi square analysis was done, Pearson Chi SquareValue $=9.890$, the $P$ value was $0.002(p<0.05)$, which was found to be statistically significant. This is a significant increase in the active cases seen in urban are as when compared to rural areas.

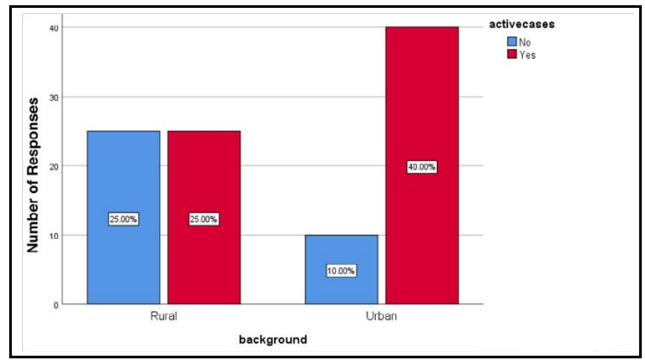

posite. Figure 8 Shows that $20 \%$ of the respondents from urban backgrounds think that they are at a higher risk of contracting the virus, where as $16 \%$ of the rural respondents think the same. Out of these, the results assessed for their $\mathrm{p}$ value and checked for their significance. Figures 3, 4, 6 and 7 were found to be statistically significant, whereas the rest were statistically insignificant.

\section{Discussion}

Highly contagious with the possibility of causing severe respiratory infections, coronavirus has quickly impacted public health systems and governments, which have responded by declaring it as a public health emergency of national concern and by adopting measures such as a nationwide lockdown to limit the outbreak [19]. Millions of lives have been altered, a stress coping mecha- nism is demanded [20]. The outbreak has undoubtedly largely affected the mental, social, financial and physical health of people. Coronavirus has brought the entire nation to a halt [21].

Figure 1 shows that $50 \%$ of the people who answered the survey questions are from urban areas and the remaining are from rural backgrounds. Studies show that since most rural populations are illiterate, and do not have the resources, they come to understand and know things very late, or in a delayed fashion [22, 23]. Figure 2 shows that most of the respondents reported that they have been getting recent updates on the pandemic, and only $25 \%$ reported the opposite. Majority of the ones who aren't receiving much information comprise the rural population.

One key factor, which should be taken into consideration is the population density [24]. Urban populations have a much higher 
Figure 5. Bar graph representing association between community background and percentage of deaths due to COVID-19. $\mathrm{X}$ axis represents the community background and $\mathrm{Y}$ axis represents the number of responses. More numbers of deaths due to coronavirus in their locality was reported by the Urban population when compared to the rural population. Chi square analysis was done, Pearson Chi SquareValue $=1.897$, the $P$ value was $0.387(p>0.05)$, was not found to be statistically significant.

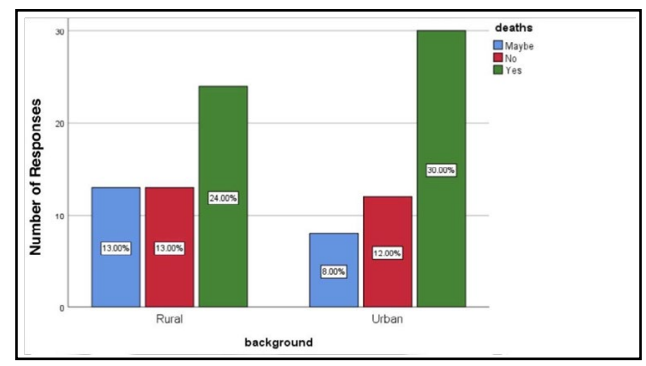

Figure 6. Bar graph representing association between community background and responses towards adequate healthcare services. $\mathrm{X}$ axis represents the community background and $\mathrm{Y}$ axis represents the number of responses towards adequate healthcare services. Most of the urban population have responded to having adequate healthcare services in their locality. Chi square analysis was done , Pearson Chi SquareValue $=18.382$, the $P$ value was $0.000(p<0.05)$, which was found to be statistically significant. There is a significantly increased adequacy of health services in the urban areas when compared to rural are as.

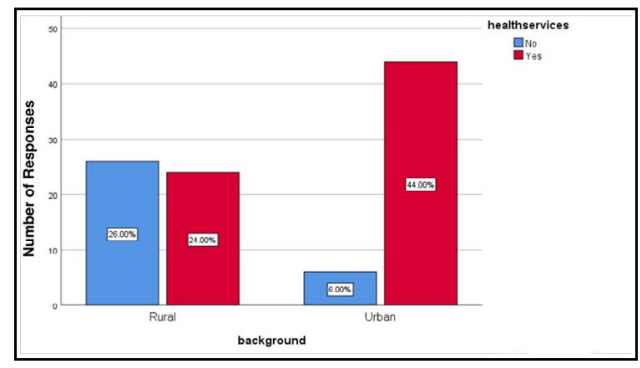

Figure 7. Bar graph representing association between community background and practice of social distancing measures. $\mathrm{X}$ axis represents the community background and the $\mathrm{Y}$ axis represents the number of responses. Higher numbers of the rural population have reported to be practicing social distancing measures for self prevention. Chi square analysis was done, Pearson Chi SquareValue $=12.000$, the $P$ value was $0.001(p<0.05)$, which was found to be statistically significant There is a significant increase seen in obedience towards preventive measures in rural population when compared to urban population.

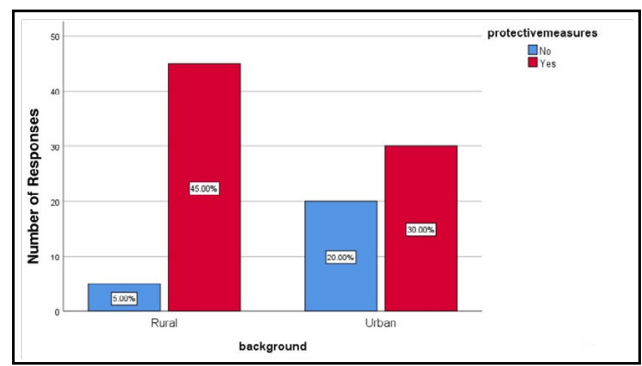

density when compared to rural areas. This plays an important role in determining the spread of coronavirus [25]. In most researches, high density populations may be sustainable in terms of economy during a lockdown or pandemic, however, they become merely defenceless in times of unprecedented disease outbreaks [26]. This is mainly accounted for by the large densely populated areas in the urban cities. A pandemic has many risks towards the millions who live in densely populated megacities [27]. Majorly, the density of the population of these cities provides an ideal environment for infections to erupt, transmit and cause havoc [28].

Figure 3 shows that urban populations are more financially stable in comparison to rural populations. This allows the urban people to buy PPE, masks, sanitisers and other equipment that can help in self protection $[29,30]$. However the income of rural people is not enough or sufficient to buy such equipment. Their low salary and minimal savings, makes it very difficult for them to stock up on these preventive measures [31]. Since most people from urban backgrounds have jobs and have savings they are fortunate enough to store food for hardships like these [32]. On the other hand, studies have shown that since rural people have low salaries, most of it is consumed on rent, housing and minimal daily food [33]. They have very low income which they use for daily survival and daily bread and butter. That income cannot be used to buy preventive and self protective measures such as masks, gloves and PPE [34]. They do not have the luxury of buying sanitisers and using it every six hours to clean their hands [35].

Figure 4 shows that more urban areas have reported with positive cases of coronavirus. One reason for this is the population den- 
Figure 8. Bar graph representing association between community background and responses about whether they think their community is at higher risk of contracting COVID-19. $\mathrm{X}$ axis represents the background and $\mathrm{Y}$ axis represents the number of the responses. More people from urban backgrounds feel that they are more prone to contracting coronavirus in comparison to rural populations. However, there is no statistical difference between the responses. Chi square analysis was done, Pearson Chi SquareValue $=2.778$, the $P$ value was $0.249(p>0.05)$, which was not found to be statistically significant.

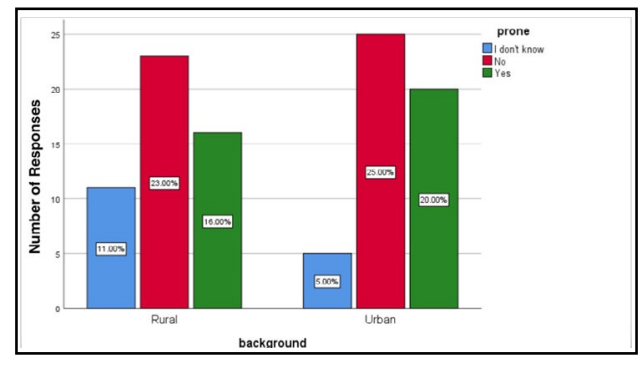

sity factor [36]. Figure 5 shows that in correspondence to figure 3, there are more deaths observed in urban areas in comparison to rural areas. High population also accounts for the higher testing that is required in the urban cities. With an increasing number of cases, the medical facilities are running out of testing equipment and so, more and more people are being left untested [37]. Untested persons may turn positive and in such a scenario, will only aggravate and intensify the spread of the viral infection, without preventive measures [38]. Mostly observed in rural areas, there are not enough medical facilities, which can be of assistance during these tough times. Presence of healthcare institutions does not account for its proper functioning and several times, do not have the appropriate medical personnel to handle very complicated or severe cases [39]. Since less funds are put in to rural areas, and also due to scarce population as established before, a pattern of low quality medical facilities has been observed in rural areas. On the other hand, the urban areas constitute plenty of government and private healthcare institutions, which cater to high end and critical cases [40]. This is why, in figure 6 , most rural respondents have responded that they do not have adequate healthcare facilities around them, in comparison to majority of urban respondents who said that they have sufficient medical clinics near by.

In the absence of a vaccine, the only reliable methods are strict adherence to social distancing and following of the lockdown and its regulations, to prevent the situation from quickly worsening [41]. Figure 7 shows that the majority of the people from rural backgrounds are practicing self preventive measures in comparison to urban populations. Studies show that most of the urban populations are less likely to be engaged in self preventive measures due to responsibilities of going to work [42, 43]. Measures such as social distancing are taken very lightly by people from urban backgrounds and they tend to have a laid back attitude towards the same [44]. They show lower intention to adopt recommended behaviors, which lead to less engagement in preventive behaviors among urban residents. Studies have shown that because of the slowing economy and upcoming recession, offices are gradually opening, compelling employees to return to work [45]. The notion of social distancing, though seems easy in theory, is quite complicated and impractical to practice in practicality. This is a major reason for the fast rate of spread among the urban population [46]. On the other hand, people from the rural backgrounds have been observed to follow the rules of the lockdown very sincerely, hence controlling the transmission of the virus, as much as they could [47]. To tackle the pandemic, the urban population has to learn to strike a balance between saving lives and economic revival. One possible explanation for rural populations to not practice social distancing, is that the current media coverage about COVID-19 prevention mostly focuses on large urban cities with high population density, which might not fully satisfy the specific needs of rural populations [48]. Thus, rural residents might not be strongly motivated to engage in adopting the appropriate preventive measures.

Figure 8 shows that more urban populations think they are at risk of contracting the coronavirus. However, the difference between the responses of urban and rural people is insignificant. This is because both communities suffer from pre existing illnesses and thus, are at high risk of getting infected, accounted for by low immunity [49]. Studies show that people from rural backgrounds suffer from a higher percentage of diseases because of low hygiene and minimal to no vaccinations $[50,51]$. They get diagnosed with diseases such as tuberculosis, oral cancer, etc. The lack of medical or health support in rural areas accounts for this fact [27]. Contaminated food products and water are a major contributing factor to the widespread disease rate in villages [52]. Urban populations on the other hand, are prevalent to diabetes and hypertension [53].

An additional aspect that needs to be mentioned is the presence of migrants in urban areas. They are carriers of infection and transmit the virus via everywhere they travel [54]. Since they do not settle in one place, there is a high possibility that a positive asymptomatic migrant can be spreading his/her infection to hundreds of people on a daily basis. On the other hand, absence of migrants in rural areas makes it a viable aspect to consider for its lower risk of contracting the infection, when seen in comparison to urban population [55].

\section{Limitations}

This study is limited due to a small scale and due to lack of awareness of rural people. Further studies and investigations should take place with a larger scale to fully understand the situation. More preventive and precautionary measures should be supplied to the rural areas along with strict quarantine and lock down measures to ensure the control of spread of the virus [56]. Awareness should also be spread among the population so that they can manage during the lockdown [57]. More ration markets should be open, for cheap buying of groceries and essential items for the poor since they do not have enough savings to do so by themselves. 


\section{Conclusion}

The present study shows that the urban population is suffering more because it has a higher risk of covid 19 due to dense population, lower immunity and noncompliance towards social distancing norms. Though the amenities are inadequate in rural areas, the spread of COVID 19 is under control in rural populations. There is an urgent need to practice social distancing and self isolation/quarantine in order to control the spread of the virus. Both communities need to take maximum precaution, such as using mouth masks, applying sanitisers, maintaining 6 feet of distance between each other, etc to protect themselves and others around them. Awareness has to be created among both populations by the health sectors and governments on various preventive measures in order to flatten the curve.

\section{Acknowledgements}

The authors are thankful to Saveetha Dental College for providing a platform to express our knowledge.

\section{References}

[1]. Khalid I, Khalid TJ, Qabajah MR, Barnard AG, Qushmaq IA. Healthcare Workers Emotions, Perceived Stressors and Coping Strategies During a MERS-CoV Outbreak. Clin Med Res. 2016 Mar;14(1):7-14.Pubmed PMID: 26847480

[2]. Velavan TP, Meyer CG. The COVID-19 epidemic. Trop Med Int Health. $2020 \mathrm{Mar} ; 25(3): 278-80$

[3]. Brundha MP, Nallaswamy D. Hide and seek in pathology-A research on game-based histopathology learning. Int. J Pharm Sci . 2019 Apr 29;10(2):1410-4

[4]. Hui DS, I Azhar E, Madani TA, Ntoumi F, Kock R, Dar O, et al. The continuing 2019-nCoV epidemic threat of novel coronaviruses to global health - The latest 2019 novel coronavirus outbreak in Wuhan, China. Int J Infect Dis. 2020 Feb;91:264-266.Pubmed PMID: 31953166.

[5]. Lu R, Zhao X, Li J, Niu P, Yang B, Wu H, et al. Genomic characterisation and epidemiology of 2019 novel coronavirus: implications for virus origins and receptor binding. Lancet. 2020 Feb 22;395(10224):565-574.Pubmed PMID: 32007145

[6]. Cascella M, Rajnik M, Cuomo A, Dulebohn SC, Di Napoli R. Features, evaluation and treatment coronavirus (COVID-19). Statpearls [internet]. 2020 Mar 8

[7]. Hopkins C, Surda P, Whitehead E, Kumar BN. Early recovery following new onset anosmia during the COVID-19 pandemic - an observational cohort study. J Otolaryngol Head Neck Surg. 2020 May 4;49(1):26.Pubmed PMID: 32366299.

[8]. Bikdeli B, Madhavan MV, Gupta A, Jimenez D, Burton JR, Der Nigoghossian C, et al. Pharmacological Agents Targeting Thromboinflammation in COVID-19: Review and Implications for Future Research. Thromb Haemost. 2020 Jul;120(7):1004-1024.Pubmed PMID: 32473596.

[9]. Hu B, Qiu J, Chen H, Tao V, Wang J, Lin H. First, second and potential third generation spreads of the COVID-19 epidemic in mainland China: an early exploratory study incorporating location-based service data of mobile devices. Int J Infect Dis. 2020 Jul;96:489-495.Pubmed PMID: 32425632.

[10]. Murthy S, Gomersall CD, Fowler RA. Care for critically ill patients with COVID-19. Jama. 2020 Apr 21;323(15):1499-500.

[11]. Feng S, Shen C, Xia N, Song W, Fan M, Cowling BJ. Rational use of face masks in the COVID-19 pandemic. Lancet Respir Med. 2020 May 1;8(5):434-6.

[12]. Gianfrancesco M, Hyrich KL, Al-Adely S, Carmona L, Danila MI, Gossec L, et al. Characteristics associated with hospitalisation for COVID-19 in people with rheumatic disease: data from the COVID-19 Global Rheumatology Alliance physician-reported registry. Ann Rheum Dis. 2020 Jul 1;79(7):859-66.

[13]. Brundha MP, Pathmashri VP, Sundari S. Quantitative changes of red blood cells in cancer patients under palliative radiotherapy-a retrospective study. Res J Pharm Technol. 2019 Feb 1;12(2):687-92.

[14]. Timothy CN, Samyuktha PS, Brundha MP. Dental pulp Stem Cells in Re- generative Medicine-A Literature Review. Res J Pharm Technol. 2019 Aug $1 ; 12(8): 4052-6$.

[15]. Wu P, Fang Y, Guan Z, Fan B, Kong J, Yao Z, et al. The psychological impact of the SARS epidemic on hospital employees in China: exposure, risk perception, and altruistic acceptance of risk. Can J Psychiatry. 2009 May;54(5):302-11.Pubmed PMID: 19497162.

[16]. Zhang Y. Epidemic Features and Control of the 2019 Novel Coronavirus. Current Chinese Medical Science 2020;01.

[17]. Prashaanthi N, Brundha MP. A comparative study between popplet notes and conventional notes for learning pathology. Res J Pharm Technol. 2018;11(1):175-8.

[18]. Ravichandran H, Brundha MP. Awareness about personal protective equipments in hospital workers (sweepers and cleaners). Int J Pharm Sci Rev Res. 2016;40(1):28-9.

[19]. Kocalevent RD, Hinz A, Brähler E. Standardization of the depression screener patient health questionnaire (PHQ-9) in the general population. Gen Hosp Psychiatry. 2013 Sep 1;35(5):551-5.

[20]. Toussaint A, Hüsing P, Gumz A, Wingenfeld K, Härter M, Schramm E, et al. Sensitivity to change and minimal clinically important difference of the 7-item Generalized Anxiety Disorder Questionnaire (GAD-7). J Affect Disord. 2020 Mar 15;265:395-401.Pubmed PMID: 32090765.

[21]. Maunder R, Hunter J, Vincent L, Bennett J, Peladeau N, Leszcz M, et al. The immediate psychological and occupational impact of the 2003 SARS outbreak in a teaching hospital. CMAJ. 2003 May 13;168(10):1245-51. Pubmed PMID: 12743065.

[22]. Lakshmi S, Rani SL, Brundha MP. Blow the balloon for the ease--A crosssectional study on wheezing patients. Drug invent. today. $2020 \mathrm{Feb} 15 ; 14(2)$.

[23]. Klugman CM. Vast tracts of land: rural healthcare culture. Am J Bioeth. 2008 Apr;8(4):57-8.Pubmed PMID: 18576260.

[24]. Zhou P, Yang XL, Wang XG, Hu B, Zhang L, Zhang W, et al. A pneumonia outbreak associated with a new coronavirus of probable bat origin. nature. 2020 Mar; 579(7798):270-3.

[25]. Shih TL, Goldman JJ. Recognizing and resolving ethical dilemmas in rural medicine. Virtual Mentor. 2011 May 1;13(5):291-4.Pubmed PMID: 23131359.

[26]. Arasaradnam RP, Bhala N, Evans C, Greenaway J, Logan R, Penman I, et al. Faecal immunochemical testing in the COVID-19 era: balancing risk and costs. Lancet Gastroenterol Hepatol. 2020 Aug;5(8):717-719.Pubmed PMID: 32526209.

[27]. Harsha L, Brundha MP. Prevalence of dental developmental anomalies among men and women and its psychological effect in a given population. J Pharm Sci. 2017 Jun 1;9(6):869.

[28]. Akel T, Qaqa F, Abuarqoub A, Shamoon F. Pulmonary embolism: a complication of COVID 19 infection. Thromb Res. 2020 Sep 1;193:79-82.

[29]. Balaji S, Brundha MP, Path DN. Awareness of About Breast Cancer among Dental Surgeons. Res J Pharm Biol Chem Sci. 2016 Aug 1;8(8):797.

[30]. Li Q, Guan X, Wu P, Wang X, Zhou L, Tong Y, et al. Early Transmission Dynamics in Wuhan, China, of Novel Coronavirus-Infected Pneumonia. N Engl J Med. 2020 Mar 26;382(13):1199-1207.Pubmed PMID: 31995857.

[31]. Kalaiselvi R, Brundha MP. Prevalence of hysterectomy in South Indian population. Res J Pharm Technol. 2016;9(11):1941-4.

[32]. Shenoy PB, Brundha MP. Awareness of polycystic ovarian disease among females of age group 18-30 years. J Pharm Sci \& Res. 2016 Aug 1;8(8):813.

[33]. Li L, Morrow M, Kermode M. Vulnerable but feeling safe: HIV risk among male rural-to-urban migrant workers in Chengdu, China. AIDS Care. 2007 Nov;19(10):1288-95.Pubmed PMID: 18071973.

[34]. Read JM, Bridgen JR, Cummings DA, Ho A, Jewell CP. Novel coronavirus 2019-nCoV: early estimation of epidemiological parameters and epidemic predictions. MedRxiv. 2020 Jan 1.

[35]. Cook AF, Hoas H. Ethics and rural healthcare: what really happens? What might help? Am J Bioeth. 2008 Apr;8(4):52-6.Pubmed PMID: 18576259.

[36]. Backer JA, Klinkenberg D, Wallinga J. Incubation period of 2019 novel coronavirus (2019-nCoV) infections among travellers from Wuhan, China, 2028 January 2020. Euro Surveill. 2020 Feb;25(5):2000062.Pubmed PMID: 32046819.

[37]. Vernillo A. Preventive ethics and rural healthcare: Addressing issues on a systems level. Am. J. Bioethics. 2008;8:61-2.

[38]. Cen Y, Chen X, Shen Y, Zhang XH, Lei Y, Xu C, et al. Risk factors for disease progression in patients with mild to moderate coronavirus disease 2019-a multi-centre observational study. Clin Microbiol Infect. 2020 Sep;26(9):1242-1247.Pubmed PMID: 32526275.

[39]. Hossain DMM, Min RM. Coronavirus: Symptoms, diagnosis, treatment and prevention (Preprint) n.d.

[40]. Jahangiry L, Sarbakh P, Reihani P, Samei S, Sohrabi Z, Tavousi M, et al. Developing and validating the risk perceptions questionnaire for COVID-19 (Risk Precept COVID-19): an application of the extended parallel process model. 
[41]. Gerhold L. COVID-19: risk perception and coping strategies.

[42]. Shancy Merlin AR, Preejitha VB, Brundha MP. Estimation of salivary $\mathrm{pH}$ in hypertensive patients with and without periodontitis. Drug invent. today. 2020 Apr 15;14(4).

[43]. Gupta M, Thakur JS, Kumar R. Reproductive and child health inequities in Chandigarh Union Territory of India. J Urban Health. 2008 Mar;85(2):2919 .

[44]. Chen H, Wu R, Xing Y, Du Q, Xue Z, Xi Y, et al. Influence of Different Inactivation Methods on Severe Acute Respiratory Syndrome Coronavirus 2 RNA Copy Number. J Clin Microbiol. 2020 Jul 23;58(8):e00958-20.Pubmed PMID: 32467359.

[45]. Yadav A. COVID-19: Prediction of Vulnerable Areas Having High Risk of Becoming Hotspots and Providing Necessary Statistics during COVID-19 Pandemic.

[46]. Júnior JG, Moreira MM, Pinheiro WR, de Amorim LM, Lima CK, da Silva CG, et al. The mental health of those whose rights have been taken away: An essay on the mental health of indigenous peoples in the face of the 2019 Coronavirus (2019-nCoV) outbreak. Psychiatry Res. 2020 Jul 1;289:113094.

[47]. Stein RA. COVID-19: Risk groups, mechanistic insights and challenges. Int. J. Clin. Pract. 2020 Aug;74(8):e13512.

[48]. Brundha MP. A Comparative Study-The Role of Skin and Nerve Biopsy in Hansen's Disease. J. Pharm. Sci. Res. 2015 Oct 1;7(10):837.

[49]. Inc. WR, Wolfram Research, Inc. Epidemic Data for Novel Coronavirus 2019-nCoV from Wuhan, China. Wolfram Research Data Repository n.d.
[50]. Chandrasekhar H, Brundha MP. Awareness of polycystic ovarian disease among females of age group 30-50 years. J. Pharm. Sci. Res. 2016 Aug $1 ; 8(8): 817$.

[51]. Dryhurst S, Schneider CR, Kerr J, Freeman AL, Recchia G, Van Der Bles AM, et al. Risk perceptions of COVID-19 around the world. J. Risk Res. 2020 Aug 2;23(7-8):994-1006

[52]. Hunter P. The spread of the COVID -19 coronavirus. EMBO Reports 2020;21.

[53]. Brundha MP, Haritha PS. Awareness of dengue fever among the parents of children coming to the dental outpatient department - A questionnaire study. International Journal of Clinicopathological Correlation 2019;3:60.

[54]. Hannah R, Ramani P, Brundha MP, Sherlin HJ, Ranjith G, Ramasubramanian $\mathrm{A}$, et al. Liquid paraffin as a rehydrant for air dried buccal smear. Res J Pharm Technol. 2019 Mar 1;12(3):1197-200.

[55]. Kumar MA, Brundha MP. Awareness about nocturia-A questionnaire survey. Res J Pharm Technol. 2016 Oct 1;9(10):1707-9.

[56]. Picozzi M, Grossi AA, Ferioli E, Nicoli F, Gasparetto A. Donation after circulatory death: when withdrawing life-sustaining treatments is ethically acceptable. Transplant. Proc. 2019;51:117-9.

[57]. Turner AI, Smyth N, Hall SJ, Torres SJ, Hussein M, Jayasinghe SU, et al. Psychological stress reactivity and future health and disease outcomes: A systematic review of prospective evidence. Psychoneuroendocrinology. 2020 Apr;114:104599.Pubmed PMID: 32045797. 